\title{
Partisipasi Politik Perempuan (Studi pada Masyarakat Kelurahan Mande Kecamatan Mpunda Kota Bima)
}

\author{
St. Nurbayan ${ }^{1}$ M.Tahir ${ }^{2}$ \\ Program Studi Pendidikan Sosiologi STKIP Bima \\ Jalan Piere Tendean Kel. Mande Tlp.Fax (0374) 42801, Bima 84191, Indonesia \\ (Email: nurbayan.st@gmail.com)
}

\begin{abstract}
Abstrak
Penelitian ini bertujuan untuk mendeskripsikan partisipasi perempuan dalam politik serta kendala yang dihadapi perempuan sehingga membuat perempuan tidak manpu bersaing dengan laki-laki secara maksimal. Sementara pada masyarakat Bima telah melibatkan perempuan secara penuh untuk terlibat dan berpartisipasi dalam dunia politik. Metode yang digunakan dalam penelitian ini adalah metode wawancara, observasi dan dokumentasi dengan pendekatan deskriptif kualitatif. Jenis penelitian yakni studi analisi (riset) terfokus pada 8 perempuan sebagai informan yang ditentukan secara purposive sampling. Data penelitian ini dianalisis dengan display data, ferifikasi data, lalu menguji keabsahan data. Topik perempuan dalam politik merupakan hal yang sangat kompleks. Penelitian ini didasarkan pada teori-teori feminisme universal dan budaya patriarki. Ada Tiga pandangan utama dan pertama, perempuan memiliki pengaruh kurang dibandingkan dengan laki-laki di daerah politik karena budaya patriarki. Para perempuan dianggap kurang mampu, memiliki posisi yang lebih rendah maupun terdegradasi ke bidang yang dianggap lembut dan karenanya sesuai untuk kaum perempuan. Kedua, politisi perempuan lebih baik karena lebih sabar dan penuh perhatian dibandingkan dengan politisi laki-laki. Terakhir, perempuan dan lakilaki memberikan kontribusi sama untuk proses politik dan kualitas kontribusi politisi tergantung pada kemampuan individu dan bukan jenis kelaminnya. Perempuan sangat penting untuk dua alasan. Pertama, keterwakilan perempuan di parlemen mendorong perempuan lain untuk masuk, meningkatkan kesetaraan gender dalam politik dan mendorong peningkatan pelaksanaan undangundang dan kebijakan yang peka gender. Mudah-mudahan, meningkatkan pengaruh dan kontribusi perempuan dapat terjadi dalam semua aspek politik dan tidak hanya bidang yang tetap sesuai dengan budaya patriarki pada masyarakat Bima. Sedangkan hambatan yang diuraikan pada bagian informasi latar belakang yang membatasi keterlibatan perempuan dalam ranah politik. Hasil penelitian menunjukkan budaya patriarki, budaya Jawa, money politics, kewajiban seharihari perempuan, metode organisasi dan media dianggap sebagai hambatan. Terlepas dari hambatan metode organisasi, hambatan lainnya semua hasil dari budaya patriarki mengakibatkan perempuan dan isu-isunya yang dianggap kurang penting dalam masyarakat Bima. Namun, bertentangan dengan informasi latar belakang, penelitian ini menunjukkan agama Islam dan nepotisme dianggap hambatan bagi perempuan dalam politik di Bima-Mande.
\end{abstract}

\section{Kata Kunci : Partisipasi, Politik, Perempuan}




\section{Pendahuluan}

Partisipasi politik menjadi tolak ukur berkembangnya pembangunan dalam suatu negara tanpa membedakan jenis kelamin laki-laki maupun perempuan, karena keterlibatan setiap warga negara menjadi syarat mutlak bagi tercapainya tujuan nasional, sehingga tujuan nasional yang hendak dicapai menjadi mudah untuk diwujudkan. Indonesia merupakan Negara yang sedang berkembang (Developing Country) dan sedang berusaha mengejar ketertinggalan untuk menjadi Negara yang maju dengan konsep pembangunan, namun dalam mengembangkan sektor kehidupan masyarakat seringkali menghadapi berbagai kendala. Salah satu kendala pemerintah dalam menerapkan konsep pembangunan adalah masalah partisipasi politik yang masih membedakan berdasarkan jenis kelamin. Seiring dengan era reformasi yang semakin terbuka ditandai dengan hidupnya nilai-nilai demokrasi dalam masyarakat tentunya memberikan kesempatan yang luas kepada setiap warga negara baik laki-laki maupun perempuan, namun perempuan hanya mendapatkan $30 \%$ hak dipilih sedangkan hak memilih telah mencapai $100 \%$. Oleh karena itu partipasi politik perempuan bukan lagi dibedakan dengan laki-laki. Dan ini menunjukan perkembangan indonesia akan mudah dicapai.

Undang-undang Pemilu No. 23 Tahun 2003 memberikan kesempatan kepada semua warga negara yang telah memenuhi persyaratan untuk turut berpartisipasi politik. Pemilu dilangsungkan secara serempak di seluruh wilayah Indonesia meskipun di beberapa derah-daerah tertentu harus menyusul akibat keterlambatan logistik yang sampai ke daerah pemilihan, namun keterlibatan perempuan dalam politik semakin memperlihatkan keterwakilannya. Hal ini terlihat pada Pemilu tahun 2014 merupakan peristiwa yang bersejarah dalam perjalanan kehidupan berbangsa.
Pelaku-pelaku yang terlibat dalam partisipasi politik memperlihatkan ketrlibatan perempuan tanpa membedakan status sosial dan pendidikan yang menjadi pengalamannya. Keterlibatan perempuan sebagai caleg dalam pemilu 2014 di Kelurahan Mande sebanyak 8 orang yang mewakili berbagaimacam partai politik.

Pemilu 2014 memiliki banyak sisi yang unik untuk dikaji. Salah satunya adalah keterlibatan perempuan dalam pemilu semakin berkembang. Pemilu dan perempuan seperti dua sisi mata uang yang tidak dapat dipisahkan, karena membahas tentang pemilu kuranglah lengkap bila tanpa menyertakan perempuan di dalamnya. Walau dalam sejarah politik di Indonesia dan negara berkembang pada umumnya, peranan perempuan memang dipandang terlambat dalam keterlibatan di dunia politik. Stigma-stigma bahwa perempuan dalam posisi domestik dianggap sebagai salah satu hal yang mengakibatkan perempuan terlambat berkiprah dalam dunia politik. Salah satu indikatornya adalah jumlah perempuan yang memegang jabatan publik masih sangat sedikit. Namun keterwakilan perempuan dalam pemilu 2014merupakan fenomena baik ditingkat elit atau pusat bahkan berimbas pada tingkatan lokal atau daerah.

Pada masyarakat sekarang, gerbang demokrasi telah terbuka dengan lebar dan peluang perempuan untuk turut mengaktualisasikan dirinya juga telah dijamin. Dengan adanya Undang-Undang Pemilu Tahun 2003 No. 12 Pasal 65 yang mengatur tentang kuota $30 \%$ sebagai salah satu syarat bagi pencalonan anggota legislatif oleh partai politik tentunya secara logika mampu mendobrak stagnasi kuantitas perempuan di wilayah publik. Pemilu 2014 memberikan kesempatan yang luas kepada perempuan, ada banyak peran yang dapat dilakukan dalam proses penting kenegaraan tersebut. Bagaimanapun juga perempuan 
merupakan salah satu entitas yang memiliki potensi, kemampuan, dan kelebihan yang tidak kalah dengan lakilaki. Atas dasar kenyataan inilah kemudian peneliti tertarik mendeskripsikan partisipasi politik perempuan di Kelurahan Mande Kecamatan Mpunda Kota Bima

\section{Tinjauan Pustaka}

\section{Partisipasi Politik Perempuan}

\section{Pengertian Partisipasi Politik Perempuan}

Khamisi (dalam Ruslan 2000:46) memberikan pengertian yang luas mengenai partisipasi politik bahwa partisipasi politik adalah hasrat seorang individu untuk mempunyai peran dalam kehidupan politik melalui keterlibatan administratif untuk menggunakan hak bersuara, melibatkan dirinya di berbagai organisasi, mendiskusikan berbagai persoalan politik dengan pihak lain, ikut serta melakukan berbagai aksi dan gerakan, bergabung dengan partaipartai atau organisasi-oraganisasi independent, ikut serta dalam kampanye penyadaran, memberikan penyadaran, memberikan pelayanan terhadap lingkungan dengan kemampuannya sendiri.

Huntington dan Nelson (1994:9) partisipasi politik adalah kegiatan warga negara yang bertindak sebagai pribadi-pribadi yang di maksudkan untuk mempengaruhi pembuatan keputusan pemerintah. Dari konsep ini memang tidak dibedakan secara tegas apakah partisipasi politik itu bersifat otonom atau mobilisasi. Hal ini terjadi menurut Huntington dan Nelson (dalam Kamarudin, 2003:94), disebabkan oleh sejumlah alasan berikut: Pertama, perbedaan antara keduanya lebih tajam dalam prinsip daripada di alam realitas. Kedua, dapat dikatakan semua sistem politik mencakup suatu campuran keduanya. Ketiga, hubungan keduanya bersifat dinamis, artinya bahwa partisipasi politik yang bersifat dimobilisasi karena faktor internalisasi pada akhirnya akan menjadi partisipasi yang bersifat otonom. Sebaliknya juga demikian. Lane (dalam Rush dan Althoff, 2000:181) menyatakan bahwa Partisipasi politik juga memiliki empat fungsi, yaitu :

a. Sebagai sarana untuk mengejar kebutuhan ekonomis,

b. Sebagai sarana untuk memuaskan suatu kebutuhan penyesuaian sosial,

c. Sebagai sarana untuk mengejar nilai-nilai khusus,

d. Sebagai sarana untuk memenuhi kebutuhan bawah sadar dan psikologis tertentu.

\section{Perempuan dan Politik}

\section{Meningkatkan}

kesetaraan

gender merupakan hal penting dalam meningkatkan tingkat partisipasi politik perempuan secara terpadu. Noerdin dan Aripurnami (2007: 19) mengemukakan bahwa fokus pada dampak otonomi daerah pada peran perempuan di ranah publik dan pengambilan keputusan. Peneliti ini menyoroti perempuan perlu memperbaiki diri melalui motivasi, retorika dan aksi feminis (Noerdin \& Aripurnami, 2007). Metode ini dapat diterapkan pada perjuangan agar menciptakan kesetaraan gender dalam dunia politik.

\section{Teori Patriarki dan Budaya Bima}

Banyak isu-isu yang dihadapi perempuan di Indonesia didasarkan pada budaya patriarki. Ini menyebabkan ketidaksetaraan gender di masyarakat (Gunew, 1990) yang merupakan sebagai, social system in which men disproportionately occupy positions of power and authority\| (Johnson, 2005). Dalam sistem sosial terwujud adanya dikotomi publik dan privat (Code, 2000; Pateman, 1989) yang contribute to maintaining and reproducing gender inequality 
(Connell, 1987; Walby, 1990; Verloo \& Roggeband, 1996 dikutip dalam Lombardo \& Verloo, 2009).11 Di Indonesia budaya secara umum merupakan patriarkal (Rinaldo, 2008; Fattore, Scotto \& Sitasari, 2010) dan mengakibatkan marginalisasi perempuan (Johnson, 2005; Parawansa, 2010) karena ini, relegates women as mothers and house workers to the home, and psychologically denies them full personhood, citizenship and human rights (Foreman, 1977; Okin, 1989; Pateman, 1988; Goldman, 1969 dikutip dalam Ferguson \& Hennessy, 2010).

Budaya Bima juga menyebabkan masalah budaya patriarki. Hirarki gender moral mempertahankan peran perempuan sebagai kunci untuk keluarga, masyarakat dan nilai-nilai bangsa. Wawasan ini, mengabadikan ketidaksetaraan gender dalam masyarakat. Selanjutnya wawasan tersebut menjadi hambatan bagi perempuan memasuki ranah politik. Menurut Adamson (2007) wawasan kesetaraan merupakan isu multidimensi dan budaya merupakan faktor penting yang mempengaruhi wawasan kesetaraan gender dalam dunia politik di Bima.

4. Keterlibatan Perempuan dalam Dunia Politik

\section{a. Peran Perempuan dalam Politik di Bima}

Partisipasi perempuan di Bima sangat rendah dibandingkan laki-laki. Keterlibatan perempuan dalam politik terbatas hanya mewakili administrasi partai tanpa memberikan pelatihan dan pemahaman dalam mensosialisasikan dunia politik. Adanya hal demikian karena menurut (Parawansa, 2010) bahwa persentase tertinggi perempuan ditemukan dalam bidang-bidang yang lembut seperti pemuda, agama dan komisi seni. Selain itu, dibandingkan laki-laki perempuan kurang mendapatkan dan menempati posisi tinggi di parlemen.

\section{b. Pentingnya Partisipasi Politik Perempuan}

Rendahnya keterwakilan perempuan di bidang politik menghasilkan implikasi lebih luas. Kehadiran perempuan dalam jabatan politik memiliki kepentingan simbolis. Menurut Johnson, Kabuchu dan Vusiya (2003 dikutip dalam Hughes, 2009) penilaian itu meningkatkan pandangan perempuan dan laki-laki terhadap kapasitas, aspirasi, dan harga diri perempuan. Selain ini, politisi perempuan berfokus pada isu-isu yang berbeda daripada politisi laki-laki (O'Regan, 2000; Swers, 2002 dikutip dalam Hughes, 2009) misalnya, isu-isu KDRT maupun hak reproduksi (Hughes, 2009). Pengaruh utama perempuan adalah mencapai increasing effective implementation of various.government programs and schemes (Kudva, 2001:541 dikutip dalam Tinker, 2004). Politisi perempuan penting agar mampu memberlakukan isu-isu perempuan dan mendorong lebih banyak perempuan memasuki bidang politik di Bima

Pada dasarnya keterwakilan perempuan dalam politik memiliki arti dan peranan yang sangat penting, bukan hanya untuk kepentingan pencapaian target 2015 yang terdapat dalam MDG ssaja tetapi juga untuk menciptakan keadilan dan kesetaraan gender yang sering banyak dipermasalahkan dan menjadi perdebatan sengit. Kehadiran perempuan di Parlemen diharapkan mampu menjadi alat kontrol jalannya roda pemerintahan, sebagai penerus aspirasi daerah pemilihannya yang 
mampu menciptakan berbagai kebijakan yang pro pembangunan memperjuangkan politik sekarang. Perempuan yang kerap kali menjadi permasalahan seperti masalah kesetaraan gender, dimana masih sering kita temui bahwa perempuan banyak dimarginalkan dan diabaikan baik karena berlatar belakang budaya, struktur sosial, maupun agama dan tak luput pula masalah aspirasi gender. Oleh karena itu dibutuhkan keterwakilan perempuan didalam Parlemen agar kepentingan perempuan dapat ditampung dan dipecahkan serta diselesaikan permasalahanpermasalahan yang terkait dengan perempuan serta anak.

Namun yang perlu diingat disini adalah bahwa keterwakilan perempuan di Parlemen juga sematamata bukanlah keterwakilan yang melalui proses instan (asal jadi), melainkan harus melalui proses dan mekanisme perekrutan serta kaderisasi yang sesuai. Karena melalui proses rekrutmen dan mekanisme kaderisasi yang sesuai dan bertahap akan menghasilkan kader-kader perempuan yang berpotensi, berkualitas, dan berkapabilitas dalam memperjuangkan suara perempuan dihadapan nasional bahkan internasional.

\section{Faktor-faktor Yang Mempengaruhi Partisipasi Politik Perempuan}

$$
\text { Surbakti (2003 }
$$

menyebutkan dua variabel penting yang mempengaruhi tinggi rendahnya tingkat partisipasi

politik seseorang. Pertama, adalah aspek kesadaran politik seseorang yang meliputi kesadaran terhadap hak dan kewahiban sebagai warga negara. Misalnya hak-hak politik, hak ekonomi, hak mendapat perlindungan hukum, hak mendapatkan jaminan sosial, dan kewajiban-kewajiban seperti kewajiban dalam sistem politik, kewajiban kehidupan sosial, dan kewajiban lainnya. Kedua, menyangkut bagaimanakah penilaian dan apresiasinya terhadap pemerintah, balk terhadap kebijakankebijakan pemerintah dan pelaksanaan pemerintahannya.

Weimar (Sastroadmodjo, 1995) menyebutkan paling tidak ada 5 faktor yang mempengaruhi partisipasi politik yakni : a. Modernisasi, b. terjadinya perubahan-perubahan struktur kelas esensial, c. pengaruh kaum intelektual dan meningkatnya komunikasi massa, d. adanya konflik di antara pemimpin-pemimpin politik, e. Adanya keterlibatan pemerintah yang semakin meluas dalam urusan sosial, ekonomi dan kebudayaan.

Milbrath (2008:

memberikan 3 alasan bervariasinya partisipasi politik seseorang adalah :

a) Alasan pertama, berkenaan dengan penerimaan perangsang politik. Keterbukaan dan kepekaan seesorang terhadap perangsang politik melalui kontak-kontak pribadi, organisasi dan melalui media massa akan memberikan pengaruh bagi keikutsertaan seseorang dalam kegiatan politik. Meskipun demikian dalam menanggapi perangsangperangsang politik itu tentu dipengaruhi oleh pengetahuan, sikap, nilai-nilai, pengalaman dan kepribadian yang dimiliki seseorang.

b) Alasan kedua, berkenaan karakteristik sosial seseorang. Status sosial ekonomi, karakteristik suku, jenis kelamin, usia keyakinan agama merupakan karakteristik sosial yang berpengaruh terhadap partisipasi politik seseorang dalam politik. 
c) Alasan ketiga, menyangkut sifat dan sisetm politik dan partai tempat seseorang itu berada. Seseorang yang hidup dalam negara-negara demokratis, partai-partai politik cenderung mencari dukungan massa dan memperjuangkan kepentingan massa. Karena itu massa cenderung berpartisipasi dalam politik.

Dalam konteks Indonesia, Arbi Sanit menyebutkan 5 faktor yang mendorong partisipasi politik masyarakat Indonesia. Pertama, adanya kebebasan berkompetisi di segala bidang, termasuk di bidang politik. Kedua, adanya kenyataan berpolitik secara lugs dan terbuka. Ketiga, adanya keleluasaan untuk mengorganisasi diri, sehingga organisasi masyarakat dan partai politik dapat tumbuh dengan subur. Keempat, adanya penyebaran sumber days politik dalam masyarakat yang berupa kekayaan dalam masyarakat. Kelima, adanya distribusi kekuasaan di kalangan masyarakat sehingga tercipta suatu perimbangan kekuatan

\section{Kendala-Kendala Partisipasi Politik} Perempuan

\section{a. Agama Islam}

Antropologis Geertz (1960; 1968) melengkapi beberapa studi etnografi tentang budaya yang ada di Indonesia. Dia percaya agama memandu masyarakat dengan memberikan motivasi yang kuat serta konsepsi tentang keberadaan (Kunin, 2003; Yarrow, 2006). Islam mempengaruhi Perdebatan tentang hal ini karena bisa mengakibatkan dukungan atau penundukan kaum perempuan Indonesia. Sebagai contoh, interpretasi berbeda untuk ayat 4:34 dalam Qur,,an bahwa:

"Kaum laki-laki adalah
pemimpin bagi kaum

perempuan. Oleh karena Allah melebihkan sebagian mereka (laki-laki) dari sebagian yang lain dan karena mereka (lakilaki) telah menafkahkan sebagian dari harta mereka. Sebab itu maka perempuan yang saleh adalah yang taat kepada Allah lagi memelihara diri ketika suaminya tidak ada. Oleh karena Allah telah memelihara mereka. Perempuan-perempuan yang kamu ragukan nusyuznya, maka nasehatilah mereka dan pisahkanlah mereka di tempat tidur mereka dan pukullah mereka (darabah).

Sebuah terjemahan ayat Qur,,an ditafsirkan darabah sebagai "pukulan, (Altorki, 2007) yang menunjukkan kaum perempuan memiliki status lebih rendah daripada kaum laki-laki (Vreede-de Stuers, 1960; Adamson, 2007). Namun, kata darabah bisa saja ditafsirkan sebagai teladan,, (Altorki, 2007). Penafsiran ini, memungkinkan perempuan memperjuangkan hak-hak persamaan (Moghadam, 2007).

Negara-negara terdiri dari penduduk mayoritas Muslim memilih hanya sedikit perwakilan legislatif nasional (Glaser \& Possony 1979; Norris \& Inglehart 2000; Paxton \& Hughes 2007). Meskipun demikian, sebuah penelitian lengkap oleh Fattore, Scotto dan Sitasari (2010: 261-75) menemukan bahwa mayoritas penduduk Indonesia mendukung kenyataan bahwa kesetaraan gender mengalami peningkatan dalam pemerintahan. Dasar supaya menciptakan perubahan sudah terwujud bagi perempuan dalam dunia politik. Namun, karena sedikitnya jumlah perempuan dalam ranah politik keyakinan ini belum tercermin dalam perubahan yang nyata. 


\section{b. Korupsi}

Kegiatan-kegiatan politik yang korup seperti money politics maupun nepotisme sehingga masalah yang mempengaruhi baik bagi politisi perempuan dan politisi laki-laki. Salah satu contoh money politics dari pemilihan gubernur pada tahun $2008 \mathrm{di}$ Jawa Timur adalah. Anggota Nahdlatul Ulama (NU) memberi sumbangan satu miliar rupiah ke sektor provinsinya serta menyediakan puluhan mobil untuk divisi perempuan (The Jakarta Post, 2008). NU mengklaim itu merupakan sumbangan tetapi contoh ini adalah kasus money politics. Nepotisme merupakan korupsi dengan jenis berbeda karena beberapa calon perempuan memiliki akses untuk maju dalam pencalonan karena suami atau orang tua politisi yang memiliki posisi yang penting dan menentukan dalam pemilihan. Sangat sulit bagi perempuan memasuki bidang politik di Bima karena budaya politik, money politics, dan nepotisme.

\section{c. Kewajiban Sehari-Hari}

Terdapat beberapa kewajiban yang dihadapi perempuan sehari-hari dari memasuki ranah politik di Bima. Kemiskinan dan rendahnya tingkat pendidikan menciptakan keadaan sulit yang melibatkan perempuan dalam dunia politik (Fattore, Scotto \& Sitasari, 2010: 272). Selain ini, mempersulit perekrutan perempuan yang memiliki kemampuan politik yang akan memungkinkan mereka bersaing atas dasar kesetaraan dengan laki-laki (Parawansa, 2010: 87). Perempuan sering mengalami hambatan disebabkan oleh, memerangi stereotipe tentang harus tinggal di rumah dengan anak-anaknya (United Nations Development Program, 2010: 86) dan tidak mempunyai waktu atau uang yang cukup untuk berpartisipasi dalam bidang politik di Malang.

Untuk dapat terlibat dalam segala aspek kegiatan politik bagi perempuan tidaklah mudah. Kondisi perempuan Indonesia yang dicapai sekarang ini terbentuk oleh adanya kendala yang menghambat partisipasi politiknya. Kendala pokok yang sering sekali dipergunakan sebagai alasan lemahnya partisipasi politik perempuan, dapat dikelompokkan menjadi dua, yakni hambatan internal dan hambatan eksternal.

Hambatan internal berupa keengganan besar perempuan untuk terlibat dalam kegiatan politik. Keengganan ini dikarenakan sosokultural mereka yang belum memungkinkan bisa aktif menyuarakna dan menyampaikan keinginan serta aspirasinya di bidang politik. Aktivitas dianggap tidak layak bagi perempuan, karena sifat-sifatnya yang jauh dari citra perempuan. Dunia politik di naggap "keras", "kotor", dan penuh dengan muslihat sehingga dianggap tidak cocok untuk citra perempuan.

Lingkungan social budaya yang kurang mendukung pengembangan potensi perempuan, antara lain wawasan orangtua, adat, penafsiran terhadap ajaran agama yang tidak tepat, tingkat pendapatan keluarga, dan system penddidikan yang diskriminatif. Masih lekatnya budaya tradisional dan kecilnya akses wanita pada penguasaan factor social ekonomi menyebabkan terbentuknya image dalam diri perempuan bahwa memang sewajarnya mereka berada di belakang pria.

Kendala eksternal menurut Afan Gaffar (2004: 45) antara lain dari birokrasi yang paternalistic, pola pembangunan ekonomi dan politik yang kurang seimbang dan kurang berfungsinya partai politik. Kendala 
pokok lemahnya partisipasi politik perempuan antara lain berada pada lingkungan social budaya yang kurang mendukung pengembangan potensi perempuan. Selain itu dapat pula bersumber dari kebijaksanaan pembangunan politik yang kurang memadai serta kurang berfungsinya partai politik. Peningkatan partisipasi politik perempuan dapat diupayakan antara lain dengan melalui pendidikan politik yang mampu menciptakan kemampuan dan kesadaran perempuan akan hak dan kewajibannya di bidang politik.

Dalam hal ini memang tidak terlepas dari keberadaan laki-laki yang secara luas mendominasi arena politik, laki-laki sangat dominan dalam memformulasikan aturan-aturan permainan politik; dan laki-laki lah yang sering mendefinisikan standar untuk evaluasi. Lebih jauh, kehidupan politik sering diatur sesuai dengan norma-norma dan nilai-nilai laki-laki, dan dalam beberapa kasus, bahkan menurut gaya hidup laki-laki. Sebagai contoh, model politik didasarkan pada ide "pemenang dan pecundang", kompetisi dan konfrontasi, bukan atas dasar saling menghormati, kolaborasi dan penciptaan konsensus. Lingkungan ini sering bertentangan dengan perempuan. Keberadaan dari model yang didominasi laki-laki ini menyebabkan perempuan menolak politik secara keseluruhan atau menolak politik gaya laki-laki. Jadi, ketika perempuan berpartisipasi dalam politik, mereka cenderung melakukannya dalam jumlah kecil.

Di antara kendala-kendala politik yang dihadapi perempuan, yang utama adalah:

1. Kelaziman "model maskulin" mengenai kehidupan politik dan badan-badan pemerintahan hasil pemilihan.
2. Kurangnya dukungan partai, seperti terbatasnya dukungan dana bagi kandidat perempuan; terbatasnya akses untuk jaringan politik, dan meratanya standar ganda.

3. Kurangnya hubungan dan kerja sama dengan organisasi publik lainnya, seperti serikat dagang (buruh) dan kelompok-kelompok perempuan.

4. Tiadanya sistem pelatihan dan pendidikan yang dibangun dengan baik, baik bagi kepemimpinan perempuan pada umumnya, maupun bagi orientasi perempuan muda pada kehidupan politik khususnya.

5. Hakikat sistem pemilihan, yang barangkali atau tidak mungkin menguntungkan bagi kandidat perempuan.

\section{d. Hak Perempuan Berpolitik}

Indonesia meratifikasi UU No. 7/1984 Convention on the Elimination of All Forms of Discrimination against Women (CEDAW) yang mengatakan bahwa Konvensi tentang Penghapusan Segala Bentuk Diskriminasi terhadap Perempuan. Dan Diskriminasi terhadap perempuan (adalah) setiap pembedaan, pengucilan atau pembatasan yang dibuat atas dasar jenis kelamin yang memiliki efek atau tujuan untuk merusak atau meniadakan pengakuan, penikmatan atau pelaksanaan oleh perempuan, terlepas dari status perkawinan mereka, atas dasar kesetaraan laki-laki dan perempuan, hak asasi manusia dan kebebasan dasar di bidang politik, ekonomi, sosial, budaya, sipil atau apapun lainnya. Lagi pula, pentingnya undang-undang lain meratifikasi. UU No. 39/1999 tentang Hak Asasi Manusia dan Pasal 45 menyatakan hak-hak perempuan merupakan hak asasi manusia (Irianto \& Hendrastiti, 2009).

\section{e. Organisasi Perempuan}

Jaringan online atau pertemuan 
jaringan perempuan sangat penting. Jaringan online internasional menghubungkan perempuan yang mencari pengetahuan dan pengalaman politik, membangun solidaritas bagi perempuan dalam politik di Malang (Kompas, 2010). Beberapa kaukus dan organisasi perempuan juga merupakan cara yang manjur untuk menciptakan jaringan dan membantu perempuan dalam politik. Kelompok-kelompok ini bekerja untuk mendukung dan memberdayakan perempuan di politik:

1. Kaukus Perempuan Parlemen Dewan Perwakilan Daerah Republik Indonesia (KPP DPD RI) (Kaukus Perempuan Parlemen, 2010).

2. Kaukus Perempuan Politik Indonesia (KPPI).

3. Kongres Wanita Indonesia (KOWANI) adalah federasi dari 78 organisasi perempuan (Kongres Wanita Indonesia, 2011).

4. Badan Musyawarah Organisasi Wanita Indonesia (BMOIWI) adalah sebuah federasi dari sekitar 28 organisasi perempuan Muslim (Badan Musyawarah Organisasi Wanita Indonesia, 2011).

5. Pusat Pemberdayaan Politik dalam Perempuan adalah jaringan 26 organisasi (Irianto \& Hendrastiti, 2009).

6. Kolasisi Perempuan Indonesia (KPI) (Koalisi Perempuan Indonesia, 2011).

\section{f. Alasan Perempuan Berpolitik}

Dikatakan, kesetaraan gender di Indonesia terus menerus diperjuangkan dan hal itu menjadi sangat penting bagi kaum perempuan. Oleh karena itu kata Roem, (2014) yang merupakan momen politik di Indonesia harus bisa dimanfaatkan dengan sebaik-baiknya oleh para perempuan di indonesia. "Kaum perempuan perlu untuk ikut andil dalam politik, termasuk sekarang ini silahkan berlomba-lomba untuk mencalonkan diri sebagai calon anggota legislatif.

Ditambahkan, pembangunan di Provinsi Nusa Tenggara Barat sendiri membutuhkan banyak peran dari kaum perempuan dan itu harus terus dorong. Perempuan dan laki-laki memiliki hak dan kewajiban yang sama dalam dunia kehidupan sosial kemasyarakatan, termasuk untuk urusan politik. Perempuan harus di dukung untuk ikut menyuarakan haknya dan dilibatkan dalam setiap pengambilan kebijakan," kata Roem.

Roem (2006 :78) berharap dari tiga kursi untuk anggota DPR dari Provinsi Nusa Tenggara Barat, dalam pemilihan Calon Anggota Legislatif Tahun 2014 ini diantaranya bisa diisi oleh perempuan. (Antara) Keterlibatan perempuan dalam dunia politik memiliki nilai strategis di Pileg, apalagi Undang Undang Pemilu mewajibkan tiap partai politik harus memenuhi kuota 30\% perempuan untuk calon legislatifnya. Untuk itu, dalam upaya mensosialisasikan peran perempuan di dalam politik tersebut Badan Pemberdayaan Perempuan dan Perlindungan Anak (BP3A) Provinsi Sumatera Selatan (Sumsel) mengadakan sosialisasi "Peran Perempuan di Dalam Dunia Politik Dalam Rangka Peningkatan Kualitas Hidup Perempuan". Kegiatan ini berlangsung pada 24 -25 Februari 2014 di Hotel Duta, Palembang. Kegiatan sosialisasi ini dihadiri langsung oleh Kepala BP3A Provinsi Sumsel Susna Sudarti, narasumber Heny Susantih dari KPU, Heru P Kasidi Deputi bidang Polsoskum Kementerian Pemberdayaan Perempuan dan Perlindungan Anak, dan Dra Eva Lidya Staf pengajar jurusan sosiologi FISIP Universitas Sriwijaya.

Diskusi berlangsung 
hangat.Meskipun saat ini banyak perempuan bisa menempuh pendidikan tinggi dan juga punya kedudukan yang sama dengan laki-laki di tempat kerja, namun tak dapat dipungkiri bahwa persoalan gender masih saja menimpa perempuan, mulai dari diskriminasi, kemiskinan, rendahnya tingkat kesehatan, pelecehan seksual. Menurut Kepala Badan Pemberdayaan Perempuan dan Perlindungan Anak Provinsi Sumsel Susna Sudarti, persoalan perempuan dapat terselesaikan jika mereka diberi akses yang besar untuk duduk di kursi parlemen agar mereka juga dapat menentukan kebijakan yang akan memihak mereka. Lanjut Susna Sudarti mengatakan, pada tahun 2009 keterwakilan perempuan dalam dunia politik masih jauh dari kuota $30 \%$. Menurutnya stigma bahwa politik itu adalah dunianya laki-laki saat ini tidak lagi relevan.

Sudah seharusnya perempuan tidak lagi hanya menjadi penonton di panggung politik, melainkan ikut terlibat di dalamnya karena dominasi laki-laki dalam pengambilan keputusan belum tentu memperhatikan kepentingan-kepentingan perempuan," ungkapnya. Ia juga menambahkan, perempuan dalam kehidupan sehari hari memiliki pengalaman khusus yang hanya dapat dipahami oleh dirinya sendiri, karenanya , perempuan lebih tahu apa yang menjadi kebutuhannya, misalnya masalah kesehatan reproduksi, kesehatan keluarga, harga Sembilan bahan pokok, pendidikan anak, kekerasan dalam rumah tangga dan lainnya. Pertimbangan mengapa sangat penting bagi perempuan untuk ikut menjadi pembuat keputusan politik. Sementara, dalam materi terakhir yang diberikan oleh Dra Eva Lidya yang juga staf pengajar jurusan Sosiologi FISIP Universitas Sriwijaya ini menyerukan agar perempuan tidak hanya berdebat dengan persoalan pemenuhan kuota $30 \%$ calon legislatif. Dengan masuknya perempuan dalam panggung politik mereka dapat menjadi penentu kebijakannya yang akan menyuarakan aspirasi perempuan, membela kepentingan mereka, dan pada akhirnya dapat memajukan kesejahteraan perempuan.

\section{Metode Penelitian}

Penelitian ini adalah penelitian studi riset dengan pendekatan deskriptif kualitatif yakni mendeskripsikan gejala yang terjadi dalam masyarakat. Informan penelitian adalah perempuan yang terlibat sebagai caleg dalam pemilu 2014, hal ini dientukan secara purposiv sampling. Teknik yang digunakan berupa wawancara, observasi dan dokumentasi. Hasil penelitian dianalisis berdasarkan reduksi data, ferifikasi data, ujia keabsahan dan kesimpulan.

\section{Hasil Penelitian}

Membahas tentang bentuk partisipasi politik maka tidak bisa lepas dari landasan teori yang menjadi pijakannya. Ada beberapa teori atau pandangan dari tokoh-tokoh yang relevan. Namun dalam hal ini peneliti akan berpijak pada dua landasan saja. Pertama, pendapat dari Rush dan Althof (1995:128) bahwa partisipasi politik dapat mengambil bentuk mulai dari menduduki jabatan politik atau administrasi dalam organisasi sedemikian rupa sampai kepada voting atau pemberian suara sebagai bentuk paling bawah dari partisipasi politik. Tidak terdapat perbedaan yang tajam didalamnya, dan orang boleh bergerak dari keadaaan yang satu dengan yang lain. Sementara itu, pendapat kedua adalah Roth dan Wilson dalam Budiardjo (1981:6) menguraikan bentuk partisipasi politik warga negara berdasarkan intensitasnya. Intensitas terendah adalah sebagai pengamat, 
intensitas menengah yaitu sebagai partisipan, dan intensitas partisipasi tertinggi sebagai aktivis. Bila di jenjangkan, intensitas kegiatan politik warga negara tersebut membentuk segitiga serupa dengan warga negara.

Dengan mengelaborasi kedua pendapat di atas dan berdasarkan hasil penelitian, maka bentuk partisipasi politik elit politik perempuan Kelurahan Mande ditunjukkan dalam berbagai bentuk, antara

lain memberikan suara dalam pemilu, mencalonkan diri sebagai anggota legislatif, mengikuti kampanye, menjadi juru kampanye, menjadi anggota penyelengara pemilu, menjadi saksi dalam pemilu, dan menjadi anggota partai politik.

Pada puncak hierarki terdapat orang-orang yang memegang jabatan politik atau administrasi dalam hal ini adalah KPU dan pengurus partai selanjutnya kategori ini dinamakan dengan aktivis. Kasus Muntafingah adalah contoh elit politik perempuan yang melibatkan diri dalam organisasi politik dengan memegang tugas dan tanggung jawab yang memberikan bayak pengaruh kepada individu lain dalam sistem politik. Dalam pelaksanaan tugasnya Ibu Muntafingah menjelaskan bahwa ketika diawal-awal masa pemilihan umum berlangsung, ia pernah ditugaskan untuk memverifikasi partai politik dengan mendatangi anggotanya satu per satu di lapangan. Cara yang ia lakukan ini merupakan salah satu tekhnis pelaksanaan verifikasi partai politik sebelum di sahkan sebagai kontestan pemilu di Kelurahan Mande.

Ibu Muntafingah bahwa sebagai pengurus partai ia memegang jabatan di bidang kehumasan atau publik relation. Bentuk partisipasi politik yang ia lakukan selama menjadi pengurus partai adalah menghadiri forum-forum diskusi, seminar, konferensi pers, phone Friend, melakukan dokumentasi media dan analisa media. Jenjang kedua dari hierarki partisipasi politik disebut dengan partisipan diuraikan dalam bentuk pencalonan diri sebagai anggota legislatif, mengikuti kampanye, dan aktif dalam diskusi informal tentang pemilu. Data dari KPU Kelurahan Mande tentang rekapitulasi daftar calon anggota legislatif menunjukkan bahwa perempuan yang dicalonkan oleh 24 partai politik berjumlah 190 orang (28\%) dari 674 orang (72\%) calon legislatif dari kalangan lakilaki. Jumlah ini tenyata belum mencapai kuota $30 \%$ seperti yang tertuang dalam Undang-Undang Pemilu No. 12 Tahun 2014. Meskipun hanya mencapai $28 \%$ bukan berarti partisipasi politik perempuan secara umum itu rendah. Hal ini dikarenakan bahwa dalam partisipasi politik ada banyak variabel yang dijadikan sebagai titik tolak dalam mengukur tingkat partisipasi. Lagi pula pencalonan sebagai anggota legislatif bukanlah satu-satunya bentuk partisipasi politik. Seperti yang ditegaskan oleh Huntington dan Nelson bahwa pemberian suara bukanlah satusatunya ukuran untuk mengukur tingkat partisipasi politik.

Dengan demikian menjadi jelas bahwa dalam partisipasi politik ada banyak variabel yang menjadi benang merah sebelum menarik suatu kesimpulan. Selain mencalonkan diri sebagai anggota legislatif, di jenjang partisipan juga dapat diuraikan bentuk partisipasi politik elit politik perempuan. Dari hasil penelitian didapatkan bahwa partisipasi politik elit politik perempuan ditunjukkan dalam bentuk aktif dalam diskusi formal dan mengikuti kampanye partai politik.

Topik perempuan dalam politik merupakan hal yang sangat kompleks. Penelitian ini didasarkan pada teori-teori feminisme universal dan budaya patriarki. Konsep feminisme yang universal menegaskan bahwa kesetaraan gender dianggap sebagai hak asasi manusia. Oleh karena itu, sangat memprihatinkan keterwakilan perempuan dalam politik di Mande-Bima tidak setara gender. Jumlah perempuan dalam bidang politik perlu 
ditingkatkan lagi. Karena pertama, untuk memastikan kesetaraan gender dalam parlemen dicapai. Karena kedua, para politisi perempuan ini dapat mencapai kesetaraan gender di masyarakat MandBima. Budaya patriarki masalah mendasar dalam masyarakat menyebabkan ketidaksetaraan gender dan mencegah keterlibatan setara kaum perempuan di dunia politik.

Sejumlah hambatan yang diuraikan pada bagian informasi latar belakang yang membatasi keterlibatan perempuan dalam ranah politik. Hasil penelitian menunjukkan budaya patriarki, budaya Jawa, money politics, kewajiban seharihari perempuan, metode organisasi dan media dianggap sebagai hambatan. Terlepas dari hambatan metode organisasi, hambatan lainnya semua hasil dari budaya patriarki mengakibatkan perempuan dan isu-isunya yang dianggap kurang penting dalam masyarakat Bima. Namun, bertentangan dengan informasi latar belakang, penelitian ini menunjukkan agama Islam dan nepotisme dianggap hambatan bagi perempuan dalam politik di Bima-Mande.

Pada kontribusi dan pengaruh perempuan dalam DRPD maupun politik partai di Malang. Tiga pandangan utama dan pertama, perempuan memiliki pengaruh kurang dibandingkan dengan laki-laki di daerah politik karena budaya patriarki. Para perempuan dianggap kurang mampu, memiliki posisi yang lebih rendah maupun terdegradasi ke bidang yang dianggap lembut, dan karenanya sesuai untuk kaum perempuan. Kedua, politisi perempuan lebih baik karena lebih sabar dan penuh perhatian dibandingkan dengan politisi laki-laki. Terakhir, perempuan dan laki-laki memberikan kontribusi sama untuk proses politik dan kualitas kontribusi politisi tergantung pada kemampuan individu dan bukan jenis kelaminnya.

Perempuan sangat penting untuk dua alasan. Pertama, keterwakilan perempuan di parlemen mendorong perempuan lain untuk masuk, meningkatkan kesetaraan gender dalam politik dan mendorong peningkatan pelaksanaan undang-undang dan kebijakan yang peka gender. Mudah-mudahan, meningkatkan pengaruh dan kontribusi perempuan dapat terjadi dalam semua aspek politik dan tidak hanya bidang yang tetap sesuai dengan budaya patriarki. Kedua, perempuan memastikan isu-isu perempuan sedang ditangani oleh parlemen. Undang-undang dan kebijakan yang peka gender akhirnya akan mengarah pada politisi perempuan dan laki-laki sama-sama menangani masalah masyarakat dan mencapai kesetaraan gender di masyarakat Bima

Perubahan ini harus dilaksanakan sehingga politik tidak lagi didominasi lakilaki, Sangat penting sehingga meningkatkan jumlah perempuan yang terlibat dalam politik di Bima dan meningkatkan pengaruh dan kontribusi politisi perempuan di DPRD Bima. Hal ini akan tergantung pada organisasi dan kaukus perempuan bekerja sama supaya agar mengurangi dampak hambatanhambatan yang diciptakan oleh budaya patriarki. Mudah-mudahan upayanya dapat menjamin kesetaraan gender ditingkatkan dan masa depan perempuan di politik ditingkatkan dan kemudian juga masyarakat Bima.

Diskusi yang mereka lakukan meskipun bersifat informal namun bermuara pada satu tujuan bagaimana mereka meyakinkan rekan kerjanya agar dalam menentukan preferensi politiknya sama dengan dirinya. Mengenai hal ini peneliti menyimpulkan bahwa elit politik perempuan dalam hal ini telah bertindak sebagai juru kampanye walaupun secara organisatoris tidak mendapat penugasan khusus dan formal dari partai. Alasan yang mendasari peneliti bahwa elit politik perempuan telah bertindak sebagai juru kampanye adalah tentang cara mereka 
mengajak dan mempengaruhi orang lain tidak jauh berbeda substansinya seperti yang disampaikan oleh juru kampanye secara umum, misalkan saja mengkampayekan tentang kerja-kerja partai, kebaikan-kebaikan dengan memilih partai tersebut, dan menampilkan figur atau sosok yang ada dalam partai.

\section{Kesimpulan}

\section{Kesimpulan}

Bentuk partisipasi politik warga negara berdasarkan intensitasnya. Intensitas terendah adalah sebagai pengamat, intensitas menengah yaitu sebagai partisipan, dan intensitas partisipasi tertinggi sebagai aktivis. Bila di jenjangkan, intensitas kegiatan politik warga negara tersebut membentuk segitiga serupa dengan warga negara. Partisipasi politik elit politik perempuan Kelurahan Mande ditunjukkan dalam berbagai bentuk, antara lain memberikan suara dalam pemilu, mencalonkan diri sebagai anggota legislatif, mengikuti kampanye, menjadi juru kampanye, menjadi anggota penyelengara pemilu, menjadi saksi dalam pemilu, dan menjadi anggota partai politik.

Partisipasi politik ada banyak variabel yang menjadi benang merah sebelum menarik suatu kesimpulan. Selain mencalonkan diri sebagai anggota legislatif, di jenjang partisipan juga dapat diuraikan bentuk partisipasi politik elit politik perempuan. Dari hasil penelitian didapatkan bahwa partisipasi politik elit politik perempuan ditunjukkan dalam bentuk aktif dalam diskusi formal dan mengikuti kampanye partai politik.

Topik perempuan dalam politik merupakan hal yang sangat kompleks. Penelitian ini didasarkan pada teoriteori feminisme universal dan budaya patriarki. Konsep feminisme yang universal menegaskan bahwa kesetaraan gender dianggap sebagai hak asasi manusia. Oleh karena itu, sangat memprihatinkan keterwakilan perempuan dalam politik di MandeBima tidak setara gender. Jumlah perempuan dalam bidang politik perlu ditingkatkan lagi. Karena pertama, untuk memastikan kesetaraan gender dalam parlemen dicapai. Karena kedua, para politisi perempuan ini dapat mencapai kesetaraan gender di masyarakat Mand-Bima. Budaya patriarki masalah mendasar dalam masyarakat menyebabkan ketidaksetaraan gender dan mencegah keterlibatan setara kaum perempuan di dunia politik.

Sejumlah hambatan yang diuraikan pada bagian informasi latar belakang yang membatasi keterlibatan perempuan dalam ranah politik. Hasil penelitian menunjukkan budaya patriarki, budaya Jawa, money politics, kewajiban sehari-hari perempuan, metode organisasi dan media dianggap sebagai hambatan. Terlepas dari hambatan metode organisasi, hambatan lainnya semua hasil dari budaya patriarki mengakibatkan perempuan dan isu-isunya yang dianggap kurang penting dalam masyarakat Bima. Namun, bertentangan dengan informasi latar belakang, penelitian ini menunjukkan agama Islam dan nepotisme dianggap hambatan bagi perempuan dalam politik di BimaMande.

Pada kontribusi dan pengaruh perempuan dalam DRPD maupun politik partai di Bima. Tiga pandangan utama dan pertama, perempuan memiliki pengaruh kurang dibandingkan dengan laki-laki di daerah politik karena budaya patriarki. Para perempuan dianggap kurang mampu, memiliki posisi yang lebih rendah maupun terdegradasi ke bidang yang dianggap lembut, dan karenanya 
sesuai untuk kaum perempuan. Kedua, politisi perempuan lebih baik karena lebih sabar dan penuh perhatian dibandingkan dengan politisi laki-laki. Terakhir, perempuan dan laki-laki memberikan kontribusi sama untuk proses politik dan kualitas kontribusi politisi tergantung pada kemampuan individu dan bukan jenis kelaminnya.

Perempuan sangat penting untuk dua alasan. Pertama, keterwakilan perempuan di parlemen mendorong perempuan lain untuk masuk, meningkatkan kesetaraan gender dalam politik dan mendorong peningkatan pelaksanaan undangundang dan kebijakan yang peka gender. Mudah-mudahan, meningkatkan pengaruh dan kontribusi perempuan dapat terjadi dalam semua aspek politik dan tidak hanya bidang yang tetap sesuai dengan budaya patriarki. Kedua, perempuan memastikan isu-isu perempuan sedang ditangani oleh parlemen. Undangundang dan kebijakan yang peka gender akhirnya akan mengarah pada politisi perempuan dan laki-laki samasama menangani masalah masyarakat dan mencapai kesetaraan gender di masyarakat Bima

\section{Saran}

Secara keseluruhan, perlu ditingkatkan penelitian tentang perempuan dalam politik, pada tingkat nasional, daerah dan lokal. Secara khusus saat ini terdapat penelitian terbatas tentang kaum perempuan dalam politik khususnya di Kelurahan Mande Bima. Sebuah saran penelitian masa depan mengenai pemeriksaan perencanaan secara mendalam, kebijakan, dan kegiatan organisasi dan kaukus perempuan harus terlibat sehingga membantu meningkatkan partisipasi perempuan di bidang politik. Penelitian dan saran berikutnya berkaitan dengan keterlibatan kelompok, akan memungkinkan petunjuk lengkap dan uraian yang dapat membimbing DPRD Bima agar dapat menciptakan perubahan diperlukan.

\begin{tabular}{llr}
\multicolumn{3}{r}{ Selain ini, metode yang paling } \\
efektif & dalam & meningkatkan \\
keterlibatan & perempuan dalam politik \\
dimulai & dengan & mendukung
\end{tabular}
perempuan bergeser dari bawah ke atas dalam bidang politik. Perempuan umumnya akan memulai minatnya dalam bidang politik di tingkat desa misalnya, dalam keterwakilan tingkat desa di Pembimbingan Kesejahatan Keluarga (PKK). Saat ini sedikit atau tidak ada informasi atau data tentang keterwakilan perempuan dalam politik tingkat desa. Sebuah saran penelitian masa depan memeriksa keterwakilan perempuan di tingkat desa dan bagaimana hal ini berhubungan dengan perempuan kemudian menjadi terlibat dalam politik lokal, daerah dan nasional. Mendorong lebih banyak perempuan menjadi terlibat dalam politik di tingkat desa bisa membantu meningkatkan partisipasi perempuan di seluruh ranah politik.

1. Elit politik perempuan hendaknya terus meningkatkan kualitas diri agar dapat melakukan banyak peran terutama peran-peran di wilayah publik yang justru banyak bersinggungan dengan kepentingan perempuan itu sendiri.

2. Elit politik perempuan perlu mengambil bagian secara lebih luas lagi dengan memberikan kontribusi lebih karena statusnya di tengah masyarakat telah di akui sebagai sosok yang mampu dan lebih dari yang lainnya.

3. Para elit politik perempuan bersama-sama dengan pemerintah, organisasi sosial masyarakat, partai politik, dan tokoh-tokoh politik hendaknya dapat bekerjasama 
dalam rangka memberikan pendidikan politik kepada masyarakat khususnya perempuan agar peningkatan partisipasi politik masyarakat dapat lebih berkualitas.

\section{Daftar Pustaka}

Alfan Alfian, M. (2009). Menjadi Pemimpin Politik: Perbincangan Kepemimpinan dan Kekuasaan. Jakarta: Gramedia Pustaka Utama. Asyhari, M. (2009). Strategi Pencapaian Kuota 30 Persen Calon Legislatif Perempuan pada Pemilu 2009. Malang: Universitas Muhammadiyah Malang.

Badan Musyawarah Organisasi Wanita Indonesia. (2011). Profil BMOIWI. dari Badan Musyawarah Organisasi Wanita Indonesia: Tersimpan di laman <http://bmoiwipusat.org/?page_id= 2 (Diakses pada Oktober 29, 2014)

Kejaksaan Republik Indonesia. (2000). Pengarusutamaan Gender. dari Kejaksaan Republik Indonesia: Tersimpan di laman <www.kejaksaan.go.id>.(Akses 20 Desember 2014)

Kongres Wanita Indonesia. (2011). KOWANI - Kongres Wanita Indonesia. dari KOWANI Kongres Wanita Indonesia: Tersimpan di laman <http://kowani.or.id/>. (Akses 29 Desember 2014)

Doyle Paul Johnson,Robert M.Z. Lawang, 1990. Teori Sosiologi Kelasik dan Moderen. Jakarta : PT. Gramedia Pustaka Utama

Hadi, 2004. Metodologi Penelitian Bandung, Bandung Pustaka Setia.

Maleong Lexy, 2005. Metode Penelitian Kualitatif, Rajawali Press, Jakarta Suharsimi Arikunto, 1999. Prosedur Penelitian Suatu Pendekatan Praktek Jakarta: Rineka Cipta.
Ghaffar, Afan dkk, 2001, Potret Perempuan: Tinjauan Politik, Ekonomi dan Hukum di Zaman Orde Baru, PSW UMY dengan Pustaka Pelajar.

Ajatrohaedi. 1986. Kepribadian Budaya Bangsa (Local Genius). Jakarta: Pustaka Jaya

Bhasin, Kamla. 1996. Menggugat Patriarki: Pengantar Tentang Persoalan Dominasi Terhadap Kaum Perempuan. Jakarta: Karyanamitra- Yayasan Bentang budaya

Budiardjo, Miriam (ed.). 1982. Partisipasi dan Partai Politik Sebuah Bunga Rampai. Jakarta: PT Gramedia

Chauvel, Richard dkk. 2005. IndonesiaAustralia: Tantangan dan Kesempatan dalam Hubungan Politik Bilateral. Granit, Jakarta

Mahmudah, Anik. 2004. Produktivitas Perempuan. Studi Analisis Produktivitas Perempuan Dalam Konsep Ekonomi Islam. Tesis Program Pascasarsaja IAIN Sunan Ampel (tidak di publikasikan) Marcoes-Natsir, Lies M dan Johan Hendrik Meuleman (ed.). 1993. Wanita Islam Indonesia dalam Kajian Tekstual dan Kontekstual. Jakarta: INIS

Mosse, Julia Cleves. 1996. Jender dan Pembangunan. Yogyakarta: Pustaka Pelajar

Muchsin, Aminah Wadud. 1994. Wanita di dalam Al-Qur'an. Bandung: Pustaka

Nurbayan, S. (2018). Perempuan Dan Keluarga (Studi Pada Perempuan Mempertahankan Keluarga Bermasalah Di Kelurahan Maggemaci Kecamatan Mpunda Kota Bima). Komunikasi Dan Kebudayaan, 4(2), 121-138

Nurbayan, S. T. (2017). Rekostruksi Gerakan Perempuan Menuju Kemenangan Dakwah 
Kampus. Jurnal Ilmiah Mandala

Education (JIME), 3(1), 342-353

Schoorl, J.W (terjemahan Soekadijo). 1984. Modernisasi: Pengantar Sosiologi Pembangunan NegaraNegara Sedang Berkembang. Jakarta: Gramedia Streng, Frederick J. 1976. Understanding Religious Life. California: Dickenson PublishingCompany

Sutopo, HB. 2002. Metodologi Penelitian Kualitatif. Dasar Teori dan Terapannya dalam Penelitian. Surakarta: Sebelas Maret University Press

Taufiq, Ahmad. 2000. Profil Wanita Islam dalam Pondok Pesantren: Kajian Tekstual dan Kontekstual. Surakarta: Fakultas Sastra Universitas Sebelas Maret 